\title{
Persepsi Mahasiswa UKM Suara Mahasiswa Universitas Indonesia Mengenai Pemberitaan Kampanye Pilpres 2019 Dari Media Online Detikcom
}

\author{
${ }^{1}$ Cirra Desianti, ${ }^{2}$ Nuri Syafrikurniasari \\ Sekolah Tinggi Ilmu Komunikasi London School of Public Relations \\ Jurusan Komunikasi Massa \\ email : ${ }^{1}$ cirradsnt@gmail.com, ${ }^{2}$ Nsyafrikurniasari@gmail.com
}

\begin{tabular}{|c|c|}
\hline ARTICLE INFO & ABSTRACT \\
\hline $\begin{array}{l}\text { Keywords: } \\
\text { Perception, } \\
\text { Student, } \\
\text { Media Online, } \\
\text { Detikcom }\end{array}$ & $\begin{array}{l}\text { One of the phenomena which are currently headlining in } 2019 \text { is the presidential } \\
\text { election campaign. The media are competing to spread the news about this } \\
\text { phenomenon to the public which aims to provide information needs concerning many } \\
\text { people, but it is unfortunate that the media competition, especially online media, do } \\
\text { not follow the rules of the online media, because it wants to be the fastest giving } \\
\text { headlines to the public to become a media that is loved. Student Voice UKM is the } \\
\text { object of this research to see how they perceive the } 2019 \text { presidential election } \\
\text { campaign from online media, to see whether online media follow the online media KEJ } \\
\text { rules as obedient or not with detikcom's background being the first online media in } \\
\text { Indonesia. That way the author makes this research using descriptive qualitative with } \\
\text { Focus Group Discussion interview techniques for UKM Student Voice, with the theory } \\
\text { used perception theory. }\end{array}$ \\
\hline
\end{tabular}

\section{PENDAHULUAN}

Media massa dipahami sebagai alat penyalur pesan. Sebagai sarana yang disebar oleh komunikator (wartawan, jurnalis) ke khalayak (pembaca, pendengar). Media massa benar-benar sebagai alat penyebar informasi yang netral sebagai tugas utamanya. tidak ada maksud lain. Kalau ada kejadian atau fenomena, itulah yang disampaikan oleh media, tanpa melebihkan bahkan mengurangi isi berita tersebut, karena itulah realitanya (Muslich, 2008).

Dari paragraf pertama sudah disinggung bahwa sudah menjadi tugas media untuk menyebarkan berita atau informasi kepada masyarakat yang didapatkan oleh wartawan. Wartawan tersebut haruslah sigap dengan keadaan atau fenomena sekitar agar dapat memberikan berita atau melapor kepada editor agar segera dinaikkan menjadi artikel di sebuah portal berita maupun surat kabar bahkan program televisi sekalipun. Berita yang akan disebarluaskan itu pun harus memenuhi salah satu nilai- nilai dalam pembuatan di sebuah berita. Karena dengan memiliki salah satu nilai tersebut, hal itu akan menjadi nilai jual tersendiri untuk sebuah berita.

Salah satu nilai yang harus dipatuhi adalah kebergunaan sebuah berita. Berguna tidaknya sebuah berita sangat tergantung pada manfaat yang diperoleh pemirsa dari setelah menyaksikan sebuah berita. Jadi sebagai jurnalis kita harus peka untuk mengetahui berita-berita yang berguna bagi pemirsa kita. Semakin besar manfaat yang diperoleh pemirsa setelah menyaksikan sebuah berita maka semakin besar kegunaan berita tersebut baginya (Harahap, 2006, p. 8).

Karena sudah berkembangnya zaman, penyebaran informasi pun sudah tidak dengan media cetak, melainkan media elektronik salah satunya media online. Dengan media online masyarakat dapat secara mudah mendapat sumber berita hanya dengan mengakses dari telepon genggam atau gadget lainnya. Selain itu kedatangan media online ternyata bisa membuat masyarakat menjadi Citizen Journalisme. 
Citizen Journalisme dapat didefinisikan sebagai praktik jurnalistik yang dilakukan oleh orang biasa, bukan wartawan profesional yang bekerja di sebuah media. Kehadiran blog dan media sosial menjadikan setiap orang bisa menjadi wartawan dalam pengertian juruwarta atau menyebarkan informasi sendiri kepada publik (Romli, 2018, p. 25-26). Karakteristik media online yang terdiri dari akutualitas, cepat, kapasitas luas, fleksibilitas, hyperlinked, tidak jarang dari karakeristik tersebut mengakibatkan menjadi sebuah boomerang bagi media online. Seperti pencemaran nama baik, pembunuhan karakter atau reputasi seseorang, hingga keakuratan sebuah berita pun dipertanyakan.

Selain itu, tidak jarang keberpihakan sebuah media dengan seseorang atau pihak atau badan yang mensupport banyak dengan media tersebut, yang mengakibatkan tidak netralnya sebuah berita karena menjunjung tinggi pihak yang mutualisme tersebut. Sudah menjadi rahasia umum jika sebuah media tidak netral dengan suatu berita yang dikarenakan ingin menjunjung tinggi pihak yang berhubungan baik dengan media tersebut, pemberitaan yang disebarluaskan pun tidak tanggung-tanggung secara vulgar bahkan keakuratannya menurun.

Perkembangan zaman mempengaruhi dampak cukup besar dalam penyebaran informasi, pun sudah tidak dengan media cetak, melainkan media elektronik salah satunya media online. Dengan media online masyarakat dapat secara mudah mendapat sumber berita hanya dengan mengakses dari telepon genggam atau gadget lainnya. Selain itu, kedatangan media online ternyata bisa membuat masyarakat menjadi Citizen Journalisme. Citizen Journalisme dapat didefinisikan sebagai praktik jurnalistik yang dilakukan oleh orang biasa, bukan wartawan profesional yang bekerja di sebuah media. Kehadiran blog dan media sosial menjadikan setiap orang bisa menjadi wartawan dalam pengertian juruwarta atau menyebarkan informasi sendiri kepada publik (Romli, 2018, p. 2526).

Dari karakteristik media online yang terdiri dari akutualitas, cepat, kapasitas luas, fleksibilitas, hyperlinked, tidak jarang dari karakteristik tersebut mengakibatkan menjadi sebuah boomerang bagi media online. Seperti pencemaran nama baik, pembunuhan karakter atau reputasi seseorang, hingga keakuratan sebuah beritapun dipertanyakan. Selain itu, tidak jarang keberpihakan sebuah media dengan seseorang atau pihak atau badan yang mensuppport banyak dengan media tersebut, yang mengakibatkan tidak netralnya sebuah berita karena menjunjung tinggi pihak yang mutualisme tersebut.

Penelitian Pew Research Center terkait dengan Jurnalistik Online, kredibilitas media online menurun dari sisi akurasi. Sebagian besar wartawan yang disurvei dalam penelitian mengatakan internet telah meningkatkan informasi yang salah. Dengan itulah menunjukkan sikap negatif kepada pihak yang tidak disukai atau ingin dijatuhkan oleh sebuah media melalui sindir-sindiran yang begitu jelas. Dan sebaliknya, jika sebuah media ingin menaik-naikkan martabat pihak yang dijunjung, tidak jarang berisikan berita yang positif (Romli, 2018, p.41).

Kecerobohan seperti ini sering terjadi pada media tidak terkecuali media online, dikarenakan dilema antara harus mengutamakan kepentingan masyarakat atau kepentingan komersial atau dari media itu sendiri. Karena dengan media tidak berpihak kepada masyarakat, media tidak mampu bertahan hidup karena tidak membela kepentingan seperti fenomena apa yang sedang terjadi di kalangan masyarakat. Disisi lain banyak pihak yang berinvestasi kepada media dengan tujuan sebagai sarana atau tempat untuk mempromosikan diri kepada masyarakat, tidak terkecuali dalam dunia politik.

Setidaknya salah satu penyebab, mengapa butuhnya media massa dalam dunia komunikasi politik, yang memiliki ciri khas yaitu membentuk opini publik. Dimana dari segi luas jangkuan media dalam menyebarkan informasi mengenai pemberitaan politik. Karena daya jangkuan media itulah yang dimanfaatkan aktor-aktor politik untuk menyebarluaskan pembicaraan politik-politik 
mereka, dengan harapan tujuan pencapaian politiknya melalui media massa bisa lebih besar ketimbang komunikasi politik lainnya.

Tidak terkecuali untuk kepentingan politik, media tidak jarang menjadikan tempat untuk berkampanye bagi orang-orang penting tersebut dengan menunjukan kepada masyarakat siapakah yang bekerja dengan baik hingga mana orang yang bekejra tidak baik, yang bertujuan untuk menjatuhkan satu sama lain. Dengan wacana awal untuk kepentingan masyarakat yang sekiranya akan memilih perwakilan rakyat agar sesuai dengan suara hati tetapi dimanfaatkan untuk kepentingan pribadi pihak yang bersangkutan. Salah satu fenomena yang berkembang di dunia internet adalah bermunculannya media propaganda atau media jurnalistik yang ternyata mengarah ke media propaganda. Saat ini banyak sekali media online atau situs berita baru. Media-media siber baru yang lebih pas di sebut "blog berita" ini dipopulerkan (share) di media sosial, khususnya oleh mereka yang "sejalan" atau "sepemahaman" dengan isi berita atau tulisan, atau "kebijakan redaksi" (editorial policy)-nya (Romli, 2018, p.162).

Umumnya, konten media-media baru ini kebanyakan copy paste berita darimedia siber mainstream, lalu "diedit" sedemikian rupa demi misi tertentu. Jadilah mereka media propaganda, yaitu media yang "hanya" bertujuan memengaruhi pendapat dan sikap publik. Sebagaimana layaknya propaganda, pemberitaan media tersebut "tidak obyektif", tetapi memberikan informasi yang dirancang dan diseting sedemikian rupa untuk memengaruhi, kadang "ngompori" (memanasmanasi) publik agar benci atau suka kepada seseorang atau sesuatu. Sebagaimana layaknya propaganda pula, konten media-media tersebut "hanya" menyampaikan fakta-fakta pilihan yang dapat menghasilkan pengaruh tertentu dan lebih bertujuan menghasilkan reaksi emosional daripada reaksi rasional (Romli, 2018, p.162).

Topik ini diangkat oleh penulis dikarenakan fenomena ketidaknetralan sebuah media dari pemberitaan yang mereka sebar sudah menjadi rahasia umum dikalangan masyarakat. Anggota Dewan Pers Agus Sudibyo, mengungkapkan ada enam jenis pelanggaran kode etik jurnalistik yang dilakukan oleh media online (media siber, cyber media) seperti Media online tidak menguji informasi atau melakukan konfirmasi. Pemanggaran ini terjadi karena media siber mengutamakan kecepatan tanpa dibarengi dengan verifikasi. Dilema kecepatan menimbulkan kesalahan pemberitaan, seperti berita tidak akurat, mencampurkan fakta dan opini yang menghakimi, tidak berimbang, tidak menyembunyikan identitas korban kejahatan susila, tidak jelas narasumbernya (Romli, 2018, p. 156).

Hal ini mempunyai resiko yang cukup besar jika terus dibiarkan, karena tujuan utama media sebagai penyebar berita adalah memberika fakta yang sebanar-benarnya kepada masyarakt tanpa ada campur tangan pendapat wartawan bahkan media itu sendiri. Karena sudah menjadi hak semua orang untuk mendapatkan berita yang sebenar-benarnya dari media yang ada.

Dari pihak sebagai penikmat berita, masyarakat juga tidak dapat dibendungi dalam sudut pandangnya, sesuai dengan apa yang dijelaskan oleh Murdock dan Golding bahwa apa yang telah diberitakan akan mendapat beragam pendapat atau persepsi yang muncul atau berkoar di balik pemberitaan tersebut. Seperti yang telah dijelaskan di paragraf sebelumnya, bahwa tidak bisa dipungkiri akan menjadi sebuah boomerang kepada objek atau subjek yang di maksud dari berita tersebut yang mengakibatkan reputasi hingga jabatan menjadi ancamannya. Sebaliknya, jika pemberitaannya membagus-baguskan atau menjunjung tinggi pihak yang diberitakan, tidak dapat dipungkiri juga banjir pujian dari masyarakat yang mendukungnya.

Tetapi sebagai masyarakat yang bijak, seharusnya mereka dapat melihat atau menyaring berita dengan baik tanpa harus menjatuhkan pihak lain, karena tidak jarang terjadi pertikaian antar kalangan yang disebabkan berita yang begitu rancu tidak sesuai dengan faktanya, itulah sebabnya 
dibutuhkan kepekaan terhadap fenomena sekitar bagi masyarakat agar tidak terbuai atau terkompori oleh pemberitaan yang belum jelas fakta sesungguhnya.

Dibutuhkanlah masyarakat yang cerdas dalam menyikapi sebuah berita, dengan masyarakat yang tinggi akan ilmu pendidikan, peka terhadap fenomena sekitar, seharusnya tidaklah mudah terpancing emosi atau perlawanan antar masyarakat dari pemberitaan yang ada. Karena masyarakat yang cerdas dan peka terhadap fenomena sekitar dapat mengukur bahkan menilai, pemberitaan seperti apa atau bagaimana yang cukup dapat didebatkan, bukan hanya sekedar mendapat informasi belaka langsung termakan berita hingga kemakan omongan dari orang sekitar. Dengan cara melihat isi pemberitaan yang ada, pertama akan sangat jelas dari judulnya yang menyudutkan atau membaik-baikan, kedua dari angle pengambilan berita, media bisa saja mengambil framing negatif atau positifnya dari pihak yang diangkat tanpa memberitakan hal sebaliknya tidak tahu positif atau negatif dari pihak tersebut, karena media hanya dibatasi oleh waktu dan ruang maka diperlukannya berita yang mendetail dengan melanjutkan isu selanjutnya dari topik pemberitaan tersebut, ketiga jika mendetail dengan melihat latar belakang media tersebut, kelengkapan informasi yang disebarkan media tersebut perlu diteliti apakah media tersebut memperhatikan atau tidak, hanya memberitakan dari satu angle atau framing saja. Dengan membaca berita dari beberapa portal untuk membanding-bandingkan sangat penting agar masyarakat tidak mudah terhasut dengan pemberitaan yang sekali lewat, apalagi hanya dari media online yang tidak mendetail isi pemberitaannya melainkan memperdulikan kecepatan intensitas berita terkini. Dengan mempunyai latar belakang pembelajaran dalam dunia jurnalistik dan penerbitan berita, penulis mengharapkan persepsi mahasiswa SUMA UI dapat memberikan pendapat dengan baik dan bijak mengenai pemberitaan kampanye pilpres 2019 yang akan datang. Selain itu dapat juga melihat bagaimana proses bekerja SUMA UI dalam mencari berita, dengan begitu akan terlihat jelas juga dari persepi yang mereka berikan kepada penulis.

SUMA UI adalah singkatan dari Suara Mahasiswa Universitas Indonesia. SUMA UI ialah Unit Kegiatan Mahasiswa yang menjadi wadah untuk mahasiswa-mahasiswi yang ingin berkecinampungan dalam bidang jurnalistik dan penerbitan. SUMA UI resmi berdiri pada 27 Juni 1992 melalui SK Rektor UI No. 036/SK/R/UI/1992. SUMA UI merupakan satu satunya organisasi pers mahasiswa tingkat universitas yang ada di UI. Dalam rangka menjalankan fungsi kontrol pers mahasiswa, sejak 2003 SUMA UI menerbitikan buletin bulatan yang bernama "Gerbatama, ini UI! ", yang hingga kini telah terbit sebanyak 67 edisi. Pemimpin perusahaan Suara Mahasiswa kali ini ialah Nova Suyanti (Tentang Suara Mahasiswa, 2012).

Alasan penulis memilih media online detikcom ialah, pertama detikcom tersebut adalah pencetus media online pertama di Indonesia, kedua detikcom adalah sosial media terbesar kedua setelah youtube yang sering diakses oleh masyarakat. Ketiga pengakses internet terbesar terdapat di generasi Millenials dan di generasi Z, yang dimana di generasi millenials itulah terdapat usia mahasiswa dan pekerja (Riset Nielsen, 2018). Keempat sesuai dengan namanya, media tersebut ingin memberikan berita tercepat kepada masyarakat dengan keaktual berita yang mereka miliki. Dan dengan hubungannya pemilik detik.com dengan salah satu kandidat pilpres, penulis ingin melihat adakah ketidak netralan dari pemberitaannya dengan situasi yang sedang terjadi saat kampanye mendatang.

\section{KERANGKA TEORITIS}




\subsection{Persepsi}

Istilah persepsi menurut Sarah Trenholm dan Arthur Jensen (dalam Mulyana, 2012, p. 179180) didefinisikan sebagai proses internal yang memungkinkan kita memilih, mengorganisasikan, dan menafsirkan rangsangan dari lingkungan kita, dan proses tersebut mempengaruhi perilaku kita. Definisi lain dikemukakan oleh Brian Fellows dimana persepsi adalah proses yang memungkinkan suatu organisme menerima dan menganalisis informasi. Menurut Rakhmat (2012, p. 51) persepsi adalah pengalaman tentang objek, peristiwa, atau hubungan- hubungan yang diperoleh dengan menyimpulkan informasi dan menafsirkan pesan. Definisi lain dikemukakan oleh Liliweri (2012, p.153). persepsi ialah proses menjadi sadar terhadap beberapa stimulus yang ada disekitar kita.

\subsection{Macam-Macam Persepsi}

Menurut Mulyana, persepsi dibagi menjadi dua yaitu persepsi terhadap objek (lingkungan fisik) dan persepsi terhadap manusia. Persepsi terhadap manusia lebih sulit dan kompleks, karena manusia bersifat dinamis. Perbedaan dari kedua macam persepsi tersebut (Mulyana, 2012, p.184), sebagai berikut :

a. Persepsi terhadap objek melalui lambang-lambang fisik, sedangkan persepsi terhadap orang melalui lambang-lambang verbal dan non verbal. Manusia lebih aktif daripada kebanyakan objek dan lebih sulit diramalkan.

b. Persepsi terhadap objek menanggapi sifat-sifat luar, sedangkan dalam persepsi terhadap manusia menanggapi sifat-sifat luar dan dalam (perasaan, motif, harapan, dan sebagainya). Kebanyakan objek tidak mempersepsi seseorang ketika seseorang mempersepsi objek-objek itu. Akan tetapi manusia mempersepsi seseorang pada saat seseorang mempersepsi mereka. Dengan kata lain persepsi terhadap manusia bersifat interaktif.

c. Objek tidak bereaksi, sedangkan manusia bereaksi. Dengan kata lain, objek bersifat statis, sedangkan manusia bersifat dinamis. Oleh karena itu, persepsi terhadap manusia dapt berubah dari waktu ke waktu, lebih cepat daripada persepsi terhadap objek. Oleh karena itu, persepsi terhadap manusia lebih berisiko daripada persepsi terhadap objek.

Sedangkan menurut Liliweri, macam-macam persepsi dibagi menjadi lima (Liliweri, 2012, 160-161), sebagai berikut :

a. Persepsi diri. Persepsi diri berbasis pada self-esteem (apa yang dikagumi) sejuah ana objek yang dipersepsi itu bernilai bagi dia. Konsep diri atau self-concept, itu dibentuk oleh bagaimana individu berpikir tentang orang lain dan menerimanya, bagaimana individu diterima dalam suatu kelompok tertentu, juga dibentuk berdasarkan pengalaman masa lalu, atau yang berbasis pada self-efficacy (asa manfaat) dari informasi yang dia terima.

b. Persepsi lingkungan. Persepsi lingkungan dibentuk berdasarkan konteks di mana informasi itu diterima.

c. Persepsi yang dipelajari. Persepsi yang dipelajari merupakan persepsi yang terbentuk karena individu mempelajari sesuatu dari lingkungan sekitar, misal dari kebudayaan dan kebiasaan teman-teman atau orang tua. Persepsi yang dipelajari (learned perception) berbentuk pikiran, ide atau gagasan dan keyakinan yang kita pelajari dari orang lain.

d. Persepsi Fisik. Persepsi fisik dibentuk berdasarkan pada dunia yang serba terukur (the tangible world), misal secara fiisik kita mendengar dan melihat sesuatu lalu diikuti dengan bagaimana kita memproses apa yang dilihat itu dalam pikiran dan akal.

e. Persepsi Budaya. Persepsi Budaya berbeda dengan persepsi lingkungan sebab persepsi budaya mempunyai skala yang sangat luas dalam masyarakat, sedangkan persepsi lingkungan menggambarkan skala yang sangat terbatas pada sejumlah orang tertentu. Persepsi budaya sangat bervariasi dari satu desa ke desa lain, dari satu kota ke kota lain, dan dari satu bangsa ke bangsa lain.

\subsection{Unsur-Unsur Persepsi}

Cirra Desianti, Nuri Syafrikurniasari (Persepsi Mahasiswa UKM Suara Mahasiswa...) 
Sereno et al menyebutkan bahwa persepsi terdiri dari tiga aktivitas, yaitu: seleksi, organisasi , dan interpretasi. Yang dimaksud seleksi sebenarnya mencakup sensasi dan atensi, sedangkan organisasi melekat pada interpretasi, yang dapat didefinisikan sebagai "meletakkan suatu rangsangan bersama rangsangan lainnya sehingga menjadi suatu keseluruhan yang bermakna" (dalam Mulyana 2012, p. 181). Unsur-unsur persepsi meliputi:

a. Sensasi. Sensasi merujuk pada pesan yang dikirimkan ke otak melalui indera, seperti indera penglihatan, pendengar, sentuhan penciuman dan pengecapan. Kemudian reseptornya adalah mata, telinga, kulit serta otot, hidung dan telinga yang menjadi penghubung antara otak dan lingkungan sekitar. Mata beraksi terhadap gelombang cahaya, telinga terhadap gelombang suara, kulit terhadap temperature dan tekanan, hidung terhadap bau-bauan dan lidah terhadap rasa. Lalu dari rangsangan yang sudah disebutkan diatas akan dikirmkan ke otak. Makna pesan yang dikirimkan ke oak harus dipelajari.

b. Atensi. Atensi tidak terletakkan karena sebelum manusia merespon atau menfasirkan kejadian atau rangsangan apapun, manusia harus terlebih dahulu memperhatikan kejadian atau rangsangan tersebut. Ini berarti bahwa persepsi masyarakat di kehadiran suatu objek untuk dipersepsi, termasuk orang lain dan juga diri sendiri. Dalam banyak kasus, rangsangan yang menarik perhatian kita cenderung kita anggap lebih penting daripada yang tidak menarik perhatian kita. Rangsangan seperti itu cenderung dianggap penyebab kejadiankejadian berikutnya.

c. Interpretasi. Meletakkan suatu rangsangan bersama rangsangan lainnya sehingga menjadi suatu keseluruhan yang bermakna interpretasi adalah tahapan penting dalam persepsi atas informasi yang diperoleh melalui satu indera atau lebih indera yang dimiliki.

\subsection{Unsur Berita}

Menurut Budyatna terdapat 5 unsur berita (Budyatna, 2012, p. 48-58), yaitu :

a. Berita Harus Akurat. Wartawan harus memiliki kehati-hatian yang sangat tinggi dalam melakukan pekerjaan mengingat dampak yang luas yang ditimbulkan oleh berita yang dibuatnya. Kehati-hatian dimulai dari kecermatannya terhadap ejaan nama, angka, tanggal, dan usia serta disiplin diri untuk sentiasa melakukan periksa-ulang atas keterangan dan fata yang ditemui. Tidak hanya itu, akurasi juga berarti benar dalam memberikan kesan umum, benar dalam sudut pandang pemberitaan yang dicapai oleh penyajian detail- detail fakta dan oleh tekanan yang dierikan pada fakta-faktanya.

b. Berita Harus Lengkap, Adil, dan Berimbang. Yang dimaksud dengan sikap adil dan berimbang adalah bahwa seorang wartawan harus melaporkan apa sesungguhnya yang terjadi. Unsur adil dan berimbang dalam berita mungkin sama sulitnya untuk dicapai seperti juga keakuratan dalam mneyajikan fakta. Selaku wakil dari pembaca atau pendengar berita, seorang wartawan harus senantiasa berusaha untuk menempatkan setiap fakta atau kumpulan fakta-fakta menurut proposinya yang wajar, untuk mengkaitkannya secara berarti dengan unsur-unsur lain, dan untuk membangun segi pentingnya dengan berita secara keseluruhan.

c. Berita Harus Objektif. Selain harus memiliki ketepatan (akurasi) dan kecepatan dalam bekerja, seorang wartawan dituntut bersikap objektif dalam menulis. Dengan sikap objektifnya, berita yang ia buat pun akan objektif, artinya berita yang dibuat tu selaras dengan kenyataan, tidak berat sebelah, bebas dari prasangka.

d. Berita Harus Ringkas dan Jelas. Pelaporan berita dibuat dan ada untuk melayani sebaikbaiknya, wartawan harus mengembangkan ketentuan-ketentuan yang disepakati tentang bentuk dan cara membuat berita. Berita yang disajikan haruslah dapat dicerna dengan cepat. Ini artinya tulisan suatu tulisan yang ringkas, jelas, dan sederhana. Tulisan berita harus tidak banyak menggunakan kata-kata, harus langsung, dan padu. 
e. Berita Harus Hangat. Karena konsumen berita menginginkan informasi segar, informasi hangat, kebanyakan berita berisi laporan peristiwa-peristiwa "hari ini" (dalam harian sore), atau paling lama, "tadi malam" atau 'kemarin' (dalam harian pagi). Media berita sangat spesifik tentang faktor-faktor waktu ini untuk menunjukkan bahwa berita-berita mereka bukan hanya "hangat" tetapi juga paling sedikitnya yang terakhir.

\subsection{Karakteristik Media Online}

Karakteristik media online sekaligus keunggulan media online dibandingkan "media konvensional" (cetak atau elektronik) identic dengan karakteristik jurnalistik online, antara lain:

a. Multimedia. Dapat memuat atau menyajikan berita/informasi dalam bentuk teks, audio, video, grafis, dan gambar secara bersamaan.

b. Aktualitas. Berisi info aktual karena kemudahan dari kecepatan penyajian.

c. Cepat. Begitu posting atau diupload, langsung bisa diakses semua orang.

d. Update. Pembaruan (updating) informasi dapat dilakukan dengan cepat baik dari sisi konten maupun redaksional.

e. Kapasitas Luas. Halaman web bisa menampung naskah sangat panjang.

f. Fleksibiltas. Pemuatan dan editing naskah bisa kapan saja dan di mana saja, juga ajdawal terbit (update) bisa kapam saja, setiap saat.

\subsection{Kerangka Teori}

Menjelaskan mengenai kerangka teori dari penelitian ini adalah, melihat bagaimana persepsi dari sebuah Unit Kegiatan Mahasiswa dari Universitas Indonesia yang bernama Suara Mahasiswa mengenai pemberitaan kampanye pemilihan presiden 2019 dari media online detikcom dengan menggunakan teori persepsi. Pemilihan UKM SUMA UI menjadi objek penelitian ini dikarenakan kesinambungannya dengan subjek penelitian yang sama-sama bekerja menjadi pers di sebuah media online, yang dimana UKM Suara Mahasiswa juga mempunyai media online yang bernama suaramahasiswa.com, dengan begitu ingin melihat bagaimana persepsi dari pengurus UKM SUMA tersebut mengenai pemberitaan kampanye pemilihan presiden 2019 dari media online detikcom.

\section{METODE PENELITIAN}

Dalam penelitian ini peneliti menggunakan metode kualitatif. Penelitian kualitatif adalah penelitian yang menghasilkan prosedur analisis yang tidak menggunakan prosedur analisis statistik atau cara kuantifikasi lainnya. Penelitian kualitatif didasarkan pada upaya membangun pandangan mereka yang diteliti yang rinci, dibentuk dengan kata-kata, gambaran holistik dan rumit. Sedangkan menurut Jane Richie, penelitian kualitatif adalah upaya untuk menyajikan dunia sosial, dan perspektifnya di dalam dunia, dari segi konsep, perilaku, persepsi, dan persoalan tentang manusia yang diteliti (Moleong, 2011, p.6).

Teknik pengumpulan data di penelitian ini menggunakan teknik FGD (Focus Group Discussion). Terdapat beberapa karakteristik narasumber juga yang mendukung keberlangsungan wawancara penelitian ini, seperti (1) aktif menjadi pengurus di UKM Suara Mahasiswa, (2) menyukai berita politik, dan (3) pertama kalinya mengikuti pemilihan presiden. Narasumber yang mengikuti Focus Group Discussion sebanyak 5 orang perempuan dengan divisi berbeda-beda dari UKM Suara Mahasiswa UI tersebut, divisinya antara lain Pemimpin Redaksi Buletin, Manajemen Media, Reporter, dan Pimpinan Redaksi Website.

Pertanyaan-pertanyaan yang dilontarkan kepada narasumber FGD sebagai berikut :

a. Apakah judul-judul pemberitaan kampanye di detikcom menarik perhatian untuk dibuka/ dibaca? Mengapa? 
b. Pemberitaan kampanye apa saja yang menarik perhatian anda dari detikcom?

c. Apa yang anda ketahui dari media propaganda?

d. Bagaimana tanggapan anda mengenai berita kampanye yang anda baca dari media detikcom? Bagaimana anda merespon dan menafsirkannya?

e. Apa saja yang anda baca yang sekiranya kurang bernilai dijadikan sebuah berita dari detikcom?

f. Apakahadahubungannya kepemilikan media (detikcom)dengan para paslon?

g. Apakah mungkin detikcom menjadi salah satu media propaganda dari fenomena)kampanye pilpres) ini? Berikan alasan.

h. Bagaimana persepsi kalian sebagai otonom pers yang bekerja dalam dunia wartawan melihat pemberitaan kampanye pilpres ini dari detikcom?

i. Apakah detikcom salah satunya yang memiliki kelemahan tersebut? Berikan contoh berita dan alasan.

j. Apakah detikcom mengutamakan kecepatan atau keakuratan? Alasan

k. Apakah dengan menjadi media online pertama di Indonesia dapat menjamin keprofesionalan dalam memberikan informasi?

1. Menurut anda, media online itu lebih baik atau tidak dari media cetak? Berikan alasan.

\section{HASIL PENELITIAN DAN DISKUSI}

Penelitian ini berupaya untuk menjawab lebih luas tentang pertanyaan peneliti atau mendeskripsikan serta membandingkan hasil temuan lapangan. Pembahasan ini mencakup serangkaian proses pengambilan data yang telah dilakukan oleh peneliti sampai pada akhirnya dapat mendeskripsikan persepsi mahasiswa UKM Suara Mahasiswa Ui mengenai pemberitaan kampanye pilpres 2019 dari media online detikcom. Penelitian ini dilakukan untuk melihat bagaimana persepsi mahasiswa UKM Suara Mahasiswa mengenai pemberitaan kampanye pilpres 2019 dari media online detikcom. FGD Responden penelitian berjumlah 5 orang perempuan. Analisis yang tertera di bab sebelumnya bahwa, responden FGD tersebut beranggapan bahwa banyak kekeliruan yang terdapat dari media online detikcom yang berakibat membuat persepsi bagi responden yaitu mempunyai tendesius terhadap salah satu paslon, yaitu nomor urut satu.

Sesuai dengan teori Uses and Gratifications dari Kriyantono bahwa pada dasarnya khalayak menggunakan media massa berdasarkan motif-motif tertentu. Media dianggap berusaha memenuhi motif khalayak. Jika motif ini terpenuhi maka kebutuhan khalayak akan terpenuhi. Pada akhirnya, media yang mampu memenuhi kebutuhan khalayak disebut media yang efektif (Kriyantono, 2017, p. 208). Media online detikcom dapat memberikan informasi yang dibutuhkan oleh khalayak atau publik dalam memberikan berita, khususnya dari penelitian ini kampanye pilpres 2019 menjadi contoh pemberitaan yang diteliti.

Narasumber mendapatkan pemberitaan yang mereka inginkan, apalagi dengan pemberitaan kampanye pilpres yang dimana semua orang membutuhkan informasi lebih luas mengenai para paslon yang berkampanye yang bertujuan agar dapat memantapkan pilihan dengan narasumber, mana sekiranya calon pasangan presiden yang dipilih kelak, tetapi disayangkan dari banyak karakteristik dan kode etik jurnalistik media online yang dimiliki detikcom tidak berjalan dengan semestinya, dimana realitanya detikcom banyak menyimpang dari ketentuan yang berlaku menjadi sebuah media, apalagi detikcom adalah pelopor media online pertama di Indonesia, yang tertanya dari persepsi narasumber yang sesama beraktivitas di media, detikcom banyak memberitakan berita kampanye dengan mengenyampingkan ketentuan media yang berlaku.Tidak sesuainya tersebut dijabarkan oleh persepsi narasumber dari teori persepsi, dimana melihat dari judul-judul pemberitaan kampanye pilpres 2019 tersebut hingga apakah detikcom termasuk media propaganda dari fenomena tersebut.

Sensasi merujuk pada pesan yang dikirimkan ke otak melalui indera, seperti indera penglihatan, pendengar, sentuhan penciuman dan pengecapan. Kemudian reseptornya adalah mata, 
telinga, kulit serta otot, hidung dan telinga yang menjadi penghubung antara otak dan lingkungan sekitar. Mata bereaksi terhadap gelombang cahaya, telinga terhadap gelombang suara, kulit terhadap temperature dan tekanan, hidung terhadap bau-bauan dan lidah terhadap rasa. Lalu dari rangsangan yang sudah disebutkan diatas akan dikirimkan ke otak. Makna pesan yang dikirimkan ke otak harus dipelajari (Liliweri, 2012, 160-161).

Hubungan dengan penelitian ini, peneliti ingin melihat dari segi penglihatan mengenai judul-judul yang menarik untuk dibaca, rangsangan dari responden pemberitaan kampanye pilpres apa saja yang menarik untuk dibaca, dan pengetahuan mengenai media propaganda. Hasil dari wawancara mengenai judul-judul pemberitaan kampanye pilpres 2019 dari detikcom mendapatkan jawaban rata-rata menarik untuk dibuka atau dilihat, dengan alasan bahwa judul-judul yang terdapat dari detikcom ialah sesuai dengan fenomena yang sedang hype saat ini, meskipun terdapat alasan yang mengungkapkan bahwa judul pemberitaan kampanye pilpres 2019 hanya sekedar click bite untuk pembaca.

Hasil dari FGD pun juga mendapatkan jawaban mengenai istilah media propaganda, para responden menjawab bahwa media propaganda ialah media yang membantu atau bekerja sama dengan pihak luar untuk mempersuasi masyarakat dari tujuan dan keuntungan pribadi tertentu. Atensi tidak terletak kan karena sebelum manusia merespon atau menafsirkan kejadian atau rangsangan apapun, manusia harus terlebih dahulu memperhatikan kejadian atau rangsangan tersebut. Ini berarti bahwa persepsi masyarakat di kehadiran suatu objek untuk dipersepsi, termasuk orang lain dan juga diri sendiri. Dalam banyak kasus, rangsangan yang menarik perhatian kita cenderung kita anggap lebih penting daripada yang tidak menarik perhatian kita. Rangsangan seperti itu cenderung dianggap penyebab kejadian-kejadian berikutnya (Liliweri, 2012, 160-161).

Hubungan dengan penelitian ini dari analisis atensi ialah ingin melihat tanggapan responden mengenai pemberitaan kampanye pilpres, bagaimana isi pemberitaan tersebut dari detikcom, melihat isi pemberitaan kampanye pilpres 2019 dari detikcom itu bernilai atau tidak untuk dijadikan sebuah berita, apakah terdapat sangkut paut isi pemberitaan yang memihak ini dengan hubungan baik antara pemilik media dengan salah satu paslon, hingga memberi tanggapan apakah detikcom menjadi salah satu media propaganda dalam fenomena kampanye pilpres tahun 2019 .

Tanggapan responden UKM Suara Mahasiswa mengenai pemberitaan kampanye pilpres 2019 dari detikcom beragam, 2 dari 3 responden menjawab bahwa detikcom tendesius terhadap salah satu paslon, karena terlihat dari isi pemberitaan yang terlihat membaik baikan salah satu paslon, sedangkan 1 orang dari 3 responden tersebut mengungkapkan bahwa berita kampanye pilpres 2019 dari detikcom sangat beragam, dari hard news, soft news, hingga features.

Opini dari responden mengenai kurang bernilainya sebuah berita kampanye pilpres 2019 dari detikcom mendapatkan banyak tanggapan yang berbeda-beda, diantaranya tidak penting karena tidak sesuai dengan kebutuhan pembaca, mengaku sebagai hiburan saja saat membaca berita tersebut, ada yang beranggapan bahwa bernilainya sebuah berita dilihat dari kefanatikan pendukung tersebut kepada para paslon.

Hasil analisis dari FGD mengenai hubungan kepemilikan media (detikcom) dengan salah satu paslon mendapat tanggapan yang hampir bulat sama, dimana responden menjawab bahwa adanya hubungan baik antara salah satu paslon dengan detikcom, terlihat dari isi pemberitaan kampanye pilpres 2019 ini dari paslon nomor urut satu mendapatkan pembawaan berita yang baik dibanding paslon nomor urut dua, tetapi masih dalam perselisihan antara kepemilikan media itu sendiri atau dari orang dalam media tersebut, entah wartawan atau bahkan pemimpin redaksi.

Responden FGD dari UKM Suara Mahasiswa juga memberi pendapat mengenai apakah detikcom salah satu yang menjadi media propaganda dari fenomena kampanye pilpres 2019 ini, dan jawaban dari responden secara keseluruhan mempunyai jawaban yang sama yaitu, iya. Dikarenakan terlihat sangat jelas dari isi pemberitaan yang telah mereka baca, apalagi detikcom menjadi media online terbesar kedua setelah Youtube, dimana orang-orang mengakses detikcom untuk mencari berita terupdate atau tercepat, hal itulah yang menjadikan detikcom menjadi sasaran empuk bagi pihak luar yang ingin mencari keuntungan, begitu juga dengan detikcom. Meletakkan suatu 
rangsangan bersama rangsangan lainnya sehingga menjadi suatu keseluruhan yang bermakna interpretasi adalah tahapan penting dalam persepsi atas informasi yang diperoleh melalui satu indera atau lebih indera yang dimiliki (Liliweri, 2012, 160-161).

Hubungan teori interpretasi dengan penelitian ini ialah, ingin melihat bagaimana persepsi mahasiswa/I UKM Suara Mahasiswa Mengenai Pemberitaan Kampanye Pilpres 2019 dari detikcom, pendapat responden yang dimana mereka sesama otonom pers melihat persoalan ini, melihat tanggapan responden apakah detikcom mengutamakan kecepatan atau keakuratan dalam pemberitaannya, apakah terjamin keprofesionalannya sebagai media online pertama di Indonesia menjadi media online yang terus mengikuti kaidah media yaitu KEJ Media Online, hingga apakah kehadiran media online sebagai pelengkap dari media cetak atau tidak.

Sebagai sesama media, UKM Suara Mahasiswa adalah otonom pers satu satunya milik Universitas Indonesia dan mempunyai kecenderungan yang sama suka memberitakan berita politik kepada publik, mereka memberikan pendapat mengenai detikcom dalam memberitakan berita kampanye pilpres 2019 tersebut, banyak yang beranggapan detikcom masih terlihat mengutip omongan orang dari asal capturean, yang dimana tidak ada perbedaan antara detikcom dengan blogblog bodong, kedua detikcom masih memberitakan pemberitaan yang tidak terlalu penting untuk di konsumsi oleh masyarakat, hanya karena mengandalkan click bite pembaca merasa dibohongi karena isi pemberitaan yang tidak sesuai dengan ekspetasi, dan harus dilihat kembali atau disaring kembali mana berita-berita yang sekiranya lumrah untuk diberitakan tidak hanya asal menyebar demi sesuai dengan fenomena yang berakibat menjadi pengkubuan opini publik.

Kelemahan yang dimiliki detikcom rata rata dari hasil FGD dengan UKM Suara Mahasiswa ialah detikcom terlalu mengandalkan click bite dari pembaca, sehingga tidak memperdulikan isi pemberitaan yang berbobot atau tidak untuk dikonsumsi, yang dimana ternyata membuat resah bagi pembaca karena tidak sesuai dengan ekspetasi mereka. Hal ini juga berhubungan dengan kelemahan yang ditimbulkan dari karakteristik media online yang terealisasikan dari detikcom.

Salah satu masalah terbesar dari media online ialah kecepatan atau keakuratan, dimana detikcom menurut responden FGD dari UKM Suara Mahasiswa masih mengandalkan kecepatan dibandingkan keakuratan, terlihat dari isi pemberitaan yang banyak menulis kata hingga kesalahan termpat dan fakta yang sebenarnya dari lapangan, tidak lupa kutipan-kutipan yang tidak jelas asalnya darimana yang mengakibatkan tidak ada perbedaan antara detikcom dengan blog-blog bodong.

Opini UKM Suara Mahasiswa mengenai terjaminnya tidak sebuah media online yang pertama berdiri di Indonesia menjadi yang profesional, dalam hal keakuratan, kredibilitas, hingga Kode Etik Jurnalistik Media Online, dan tanggapan dari responden beragam, pertama tergantung dari pimpinan yang melihat media online ini sebagai peluang seperti apa, jika melihat sebagai provite income mungkin itu juga salah satu alasan yang benar, karena sekarang semua publik mengakses berita dari media online salah satunya detikcom, kedua ada yang beranggapan bahwa sebagai pelengkap saja media online dari media cetak.

Sama halnya dengan pertanyaan diatas, apakah kehadiran media online menjadi pelengkap atau boomerang bagi media cetak, tanggapan dari responden FGD UKM Suara Mahasiswa tidak berbeda jauh dengan pertanyaan sebelumnya dimana melihat lagi peluang apa yang ingin diraih dari pemilik jika mempunyai media online apalagi mempunyai kedua media tersebut salah satunya dengan media cetak, ada juga yang beranggapan bahwa media online sebagai pelengkapan media cetak, yang dimana media online sangat cepat keupdatean beritanya tetapi memang untuk isi tidak sedetail media cetak, hanya saja media cetak membutuhkan waktu setidaknya 12 jam sampai satu hari untuk membertikan yang sedang headline.

\section{SIMPULAN}


Menjawab hasil tujuan penelitian mengenai persepsi mahasiswa/I UKM Suara Mahasiswa Universitas Indonesia mengenai pemberitaan kampanye pilpres 2019 dari media online detikcom, dapat disimpulkan bahwa meskipun detikcom menjadi media online pertama di Indonesia kurang berbobot dalam memberikan berita salah satunya kampanye pilpres 2019 ini, pertama seperti terdapat di beberapa artikel detikcom tidak sesuai dengan isu-isu sesungguhnya yang terdapat dilapangan dimana tidak menjamin keakuratan memberitakan, kedua detikcom terlalu mengandalkan clickbait, meskipun judul menarik untuk dibuka tetapi disayangkan judul tersebut pemberitaan kampanye pilpres dengan isi beberapa artikel ditemukan tidak sesuai dengan semestinya, ketiga detikcom terlihat di beberapa artikel tidak netral terhadap pemberitaan kampanye pilpres tersebut karena kata-kata dari isi pemberitaan seperti membaik-baikan salah satu paslon yang berarti detikcom tendesius ke paslon tersebut, karena diragukan oleh para responden bahwa dengan isi pemberitaan yang membaik-baikan salah satu paslon detikcom menjalin hubungan baik kesalah satu kandidat tersebut yang mengakibatkan pemberitaan terlihat tidak netral, keempat dari semua pernyataan diatas bisa disimpulkan juga bahwa detikcom ialah media propaganda karena terlihat sangat jelas dari isi pemberitaan yang telah mereka baca, apalagi detikcom menjadi media online terbesar kedua setelah Youtube, dimana orang-orang mengakses detikcom untuk mencari berita terupdate atau tercepat, hal itulah yang menjadikan detikcom menjadi sasaran empuk bagi pihak luar yan ingin mencari keuntungan, begitu juga dengan detikcom.

\section{Saran}

Adapun yang menjadi saran dalam penelitian ini adalah, pertama penelitian selanjutnya diharapkan untuk dapat memfokuskan penelitian dengan cara mewawancarai pakar atau ahli jurnalis mengenai media atau isi pemberitaan kampanye dari media online detikcom dan juga menggunakan teori uses and gratification, agar hasil penelitian ini semakin lengkap dan berguna bagi masyarakat luas. Kedua, peneliti berharap agar UKM Suara Mahasiswa UI lebih banyak membaca pemberitaan dari berbagai jenis media online Indonesia agar menjadi pembanding dan menjadi model untuk kegiatan aktifitas UKM Suara Mahasiswa UI.

\section{DAFTAR PUSTAKA}

Al-Qadri, B. (2016). Persepsi Masyarakat Tentang Pemberitaan Delik Kesusilaan Pada Media Elektronik di Kecamatan Manggala Kota Makassar, XIII. Makassar: Universitas Mataram. Diperoleh dari E-Journal http://ojs.unm.ac.id/index.php/supremasi/article/viewFile/2812/1513.

Budyatna, M. (2012). Jurnalistik: Teori \& Praktik.Bandung: PT Remaja Rosdakarya

Hamad, I. (2004). Konstruksi Realitas Politik Dalam Media Massa. Jakarta: Granit. Diperoleh dari E-book:

https://books.google.co.id/books?hl=en\&lr=\&id=BkEB7gJQMLQC\&oi=fnd\&pg=PA5\&d $\mathrm{q}=$ jurnal+Konstruksi+Realitas+Politik+Dalam+Media+Massa\&ots=khXWeRkixD\&sig=W IUg1kbLe7bjwLZrWIPPiRJw8N0\&rediresc=y\#v=onepage \&q=jurnal\%20Konstruksi\%20R ealitas\%20Politik\%20Dalam\%20Med ia\%20Massa\&f=false

Krisyantono, R. (2017). Teknik Praktis :Riset Komunikasi.Jakarta : Kencana.

Liliweri, A. (2012). Komunikasi Serba Ada Serba Makna.Jakarta: Kencana.

Mulyana, D. (2012). Ilmu Komunikasi Suatu Pengantar. Bandung: Rosda.

Muslich,M. (2008). Kekuasaan Media Massa Mengontruksi Realitas. Diperoleh dari EJournal: $\quad$ http://sastra.um.ac.id/wp-content/uploads/2009/10/Kekuasaan-Media-MassaMengontrukRealitas-Masnur-Muslich.pdf. Pukul 14.47. 
Mustaqim, N. (2011). Persepsi Masyarakat Tentang Acara Infotainment Insert Di Trans TV (Studi Kasus di Desa Ngelokulon Kecamatan Mijen Kabupaten Demak), XII. Semarang: Institut Agama Islam Negeri Walisongo. Di peroleh dari E-Journal: http://eprints.walisongo.ac.id/5266/1/051211 069.pdf.

Nurkhasanah, Y. (2016). Persepsi dan Motivasi Ibu Terhadap Pemilihan Ponpes Sebagai Tempat Pendidikan Bagi Anak. Semarang: Universitas Islam Negeri (UIN) Walisongo Semarang, XII. Di peroleh dari E-Journal: file:///Users/cirradesianti/Downloads/1465-3376-2-PB.pdf

Pawito. (2009). Komunikasi Politik: Media Massa Dan Kampanye Pemilihan. Yogyakarta: Jalasutra.

Pemilu. (2007). Pelaksanaan Pemilu 2019 akan dilaksanakan serentak untuk Pemilu Legislatif (Pileg 2019) dan Pemilu Presiden ( Pilpres 2019 ). (2018, Oktober 22). Diperoleh dari EJournal: http://www.pemilu.com/pemilu-2019/.

Pureklolon, T, T. (2017). Komunikasi Politik : Mempertahankan Integrasi Akademisi, Politikus, dan Negarawan. Jakarta : PT Gramedia Pustaka Utama.

Rakhmat, J. (2011). Sosiologi Komunikasi. Bandung : PT Remaja Rosdakarya

Romli, A, S. (2018). Jurnalistik Online : Panduan Mengelola Media Online. Bandung: Nuansa Cendekia.

Roem, R, E. (2011). Persepsi Masyarakat Tentang Peran Media Cetak Lokal Dalam Mitigasi Bencana Alam, IX.Di peroleh dari EJournal:http://repository.upnyk.ac.id/2450/1/Elva_Ronaning_Roem.pdf 